\title{
Orbital frequencies in the carbonate sedimentary record: distorted by diagenesis?
}

Received: 18 December 2003 / Accepted: 22 January 2004 / Published online: 2 March 2004

(C) Springer-Verlag 2004

\begin{abstract}
The most important archive of Earth's climate change through geologic history is the sedimentary rock record. Rhythmic sedimentary alternations are usually interpreted as a consequence of periodic variations in the orbital parameters of the Earth. This interpretation enables the application of cyclostratigraphy as a very precise chronometer, when based on the assumption that orbital frequencies are faithfully recorded in the sedimentary archive. However, there are numerous uncertainties with the application of this concept. Particularly in carbonates, sediment properties such as mineralogical composition and fossil associations are severely altered during post-depositional alteration (diagenesis). We here point out that the assumption of a 1:1 recording of orbital signals in many cases is questionable for carbonate rhythmites. We use computer simulations to show the effect of diagenetic overprint on records of orbital signals in the carbonate record. Such orbital signals may be distorted in terms of frequency, amplitude, and phase by diagenetic processes, and cycles not present in the insolation record may emerge. This questions the routine use of carbonate rhythmites for chronostratigraphic dating.
\end{abstract}

Keywords Limestone-marl alternations · Differential diagenesis - Computer simulation - Orbital frequencies . Rhythmites

\footnotetext{
H. Westphal (

Department for Paleontology,

University of Erlangen,

Loewenichstr. 28, 91054 Erlangen, Germany

e-mail: westphal@pal.uni-erlangen.de

Tel.: +49-09131-8522967

Fax: +49-09131-8522690

F. Böhm

GEOMAR Research Center,

Wischhofstr. 1-3, 24148 Kiel, Germany

\section{S. Bornholdt}

Interdisciplinary Center for Bioinformatics, University of Leipzig,

Kreuzstr. 7b, 04103 Leipzig, Germany
}

\section{Introduction}

The interpretation of rhythmic and cyclic sediment successions as a record of temporal signals is a central topic of modern sedimentology (e.g., de Boer and Smith 1994; Einsele et al. 1991; Fischer and Bottjer 1990; Herbert and Fischer 1986). Since the study of the Late Pleistocene by Hays et al. (1976), the concept of orbital forcing (cyclic variations of the orbital parameters of the Earth influencing climate with periodicities of about 20, 40, 100, and $400 \mathrm{ka}$ [kilo years]) has become a particularly important approach and is employed for process studies, cyclostratigraphic correlations, and chronostratigraphic calibration (e.g., de Boer and Smith 1994; Fischer and Bottjer 1990). Orbital signals are thought to be translated into the rock record, e.g., via fluctuations in temperature, sea level, or currents, as variations in mineralogical composition, fossil assemblage, or sedimentary structures such as lamination and bioturbation. The discovery of rhythmic sedimentary successions as manifestation of climate change even in non-glacial times was a breakthrough in climate research (Herbert and Fischer 1986). It provided the link between orbital cycles (precession, eccentricity, and obliquity) and processes on the Earth, and resulted in the detection of orbital signals in many ancient sedimentary successions (e.g., Arthur et al. 1986; de Boer and Wonders 1984; Schwarzacher 1987b). The method of using sedimentary cycles for astronomical high-resolution dating of stratigraphic sequences has proven useful for many successions throughout the geological record (e.g., Hilgen et al. 1993; Schwarzacher 1987a; Shackleton et al. 2000). This chronostratigraphic approach is based on the fundamental assumption that a significant part of the orbital cyclicity, manifest as insolation changes, is translated into sedimentary sequences without considerable modification of the orbital forcing frequencies. A summary of theory and application of the orbital forcing ("Milankovitch") theory on stratigraphy is given by Hinnov (2000).

An important difficulty in interpreting sedimentary successions as temporal records is that the sediment 
column never represents temporal changes of sedimentary influx through time in a precisely linear manner (Herbert 1994). Distortions of the record by variations in sedimentation rate and by penecontemporaneous disturbances of the sediment such as bioturbation have been addressed in numerous studies (e.g., Herbert 1994; Kominz 1996; Weedon 2003, p.129 ff). The resulting effects including the suppression of higher frequencies and the generation of harmonics are well understood (Herbert 1994; Weedon 2003 , p.129 ff). However, in addition to those disturbances potentially present in any sedimentary succession, siliciclastic and calcareous rhythmites alike, an additional source of distortion is inherent to calcareous rhythmites: differential diagenesis. The term differential diagenesis (Reinhardt et al. 2000; Westphal et al. 2000) describes that the intercalated lithologies (limestone beds and interlayers) have undergone different diagenetic paths, e.g., with respect to compaction. While variations of sedimentation rate usually reach a factor of $1: 2$ to $1: 4$ (Herbert 1994), differential compaction approach a much higher ratio (Munnecke et al. 2001) and therefore can lead to even more severe distortions. Unrecognized distortions in the time-depth relationship lead to smearing and splitting of spectral peaks (Schiffelbein and Dorman 1986; Weedon 1989). The present study focuses on this specific property of calcareous rhythmites which, similar to siliciclastic rhythmites, commonly are interpreted as archives of orbital signals (among many others: Barron et al. 1985; Bellanca et al. 1996; Cleaveland et al. 2002; Hinnov et al. 2000; Hilgen et al. 2003). Calcareous rhythmites, which include the well-known class of limestone-marl and limestone-shale alternations, are characterized by periodic intercalations of distinct types of rocks: Limestone beds in such rhythmites usually are cemented and uncompacted to slightly compacted. In contrast, the marl or shale interlayers always are strongly compacted (e.g., Ricken 1986, 1987, 1992). This is one expression of the characteristic differential diagenesis of calcareous rhythmites where limestone beds follow a different diagenetic path than marl or shale interlayers (e.g., Munnecke and Samtleben 1996; Westphal et al. 2000). Carbonate diagenesis involves considerable redistribution of calcium carbonate by processes of dissolution and cementation, potentially leading to a thorough reorganization of various sediment parameters overprinting and disguising primary signals.

For meaningful interpretation of such rhythmites, the fundamental question needs to be discussed whether such periodic alternations of limestone beds and interlayers always represent a faithful record of environmental rhythms. A number of recent observations suggest a careful scrutiny of this hypothesis. For example, diagenetically inert organic microfossil assemblages, which are sensitive to environmental changes, have been shown to lack systematic differences between limestone beds and marl interlayers of several rhythmic successions (Courtinat 1993; Westphal et al. 2000, 2004). This implies that the rhythmic alternation of lithologies might not directly reflect environmental fluctuations. Another frequent observation is the presence of significant variations in the rock record at frequencies not present in the orbital forcing signal. For example, in Miocene rhythmites from the slope of Great Bahama Bank, drilled during ODP Leg 166, a prominent non-orbital 11-ka cyclicity is present. Moreover, in these Miocene rhythmites a discrepancy exists between power spectra recorded in gamma-ray signals and in stable isotope data, where the first show several stronger high-frequency peaks than the latter (Eberli 2000). Extra peaks usually are interpreted either as harmonics and combination tones of the orbital periods, or are thought to indicate nonlinearity in the climate's response to orbital forcing (Elkibbi and Rial 2001). However, it is as yet unknown exactly what nonlinear mechanisms in the climate system could be responsible (Elkibbi and Rial 2001). A further unexplained phenomenon is a strong shift in amplitude as observed in some calcareous successions where the strength of the eccentricity signal is far out of proportion compared to the other orbital frequencies (Cleaveland et al. 2002). These dynamical phenomena are not easily explained by a one to one recording process of a pure orbital signal where each orbitally caused fluctuation in insolation is represented by a lithology change. Another, at first sight unrelated, observation points at strong dynamical processes in the course of transmission and recording of environmental signal in calcareous rocks. In the aftermath of the K/T boundary event, D'Hondt et al. (1996) observe a strong cyclicity in South Atlantic sediments, reminiscent of a damped oscillation triggered by a strong perturbation at the event. While a possible cause could be a reverberation of the oceanographic system, as discussed by these authors, dynamical processes in the diagenetic system could in principle generate a similar phenomenology.

One link in the recording chain of environmental signals in calcareous rhythmites is an explicitly dynamical process: the diagenesis of the carbonate succession. Despite this obvious possibility of serious modifications of sediment properties, careful discussions of possible effects of diagenetic dynamics on the environmental (orbital) record in calcareous rhythmites are still rare. This paper aims at contributing to a much-needed critical discussion on the preservation of orbital records in calcareous rhythmites.

\section{Approach}

Calcareous sediments, including calcareous rhythmites, are prone to thorough diagenetic alterations that may considerably modify sediment properties (such as mineralogical composition, fossil associations, geochemical proxies, geophysical properties; e.g., Bathurst 1987, 1991; Dullo 1984; Frank et al. 1999). In addition, calcareous rhythmites are characterized by differential diagenesis where limestone beds undergo pronouncedly different modifications than marl or shale interlayers (Munnecke and Samtleben 1996; Westphal et al. 2000). Transport of 

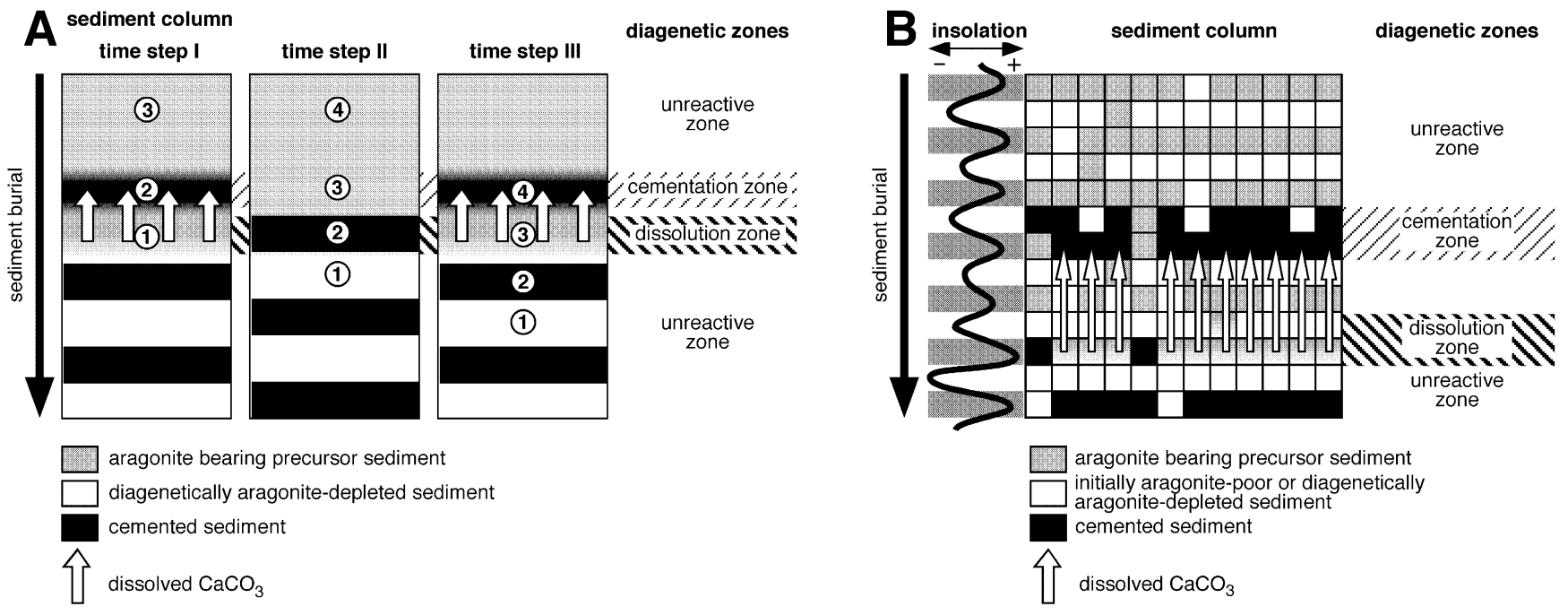

Fig. 1 A Simplified diagenesis model after Munnecke and Samtleben (1996). Sediment moves through stable diagenetic zones where aragonite dissolution and calcite cementation take place. Three time steps are shown where the sedimentary column is progressively buried. In time step I, layer 2 is cemented by calcite cement derived from dissolution of aragonite in layer 1. In time step II, the cemented layer 2 enters the aragonite dissolution zone, but the aragonite present in layer 2 is "sealed" by cement, so little to no dissolution takes place; therefore layer 3 is not being cemented. In time step III, the uncemented layer 3 enters the aragonite dissolution zone, aragonite is dissolved and reprecipitated as calcite cement in layer 4 . This model explains potentially self-

considerable amounts of dissolved calcium carbonate from the marl or shale interbeds and its reprecipitation as cement in limestone beds leads to extensive reorganization of the sediment. Limestone beds receive cement and are mechanically stabilized, and at the same time, marl layers are strongly compacted ("receiver" and "donor" beds of Bathurst 1971). This differential alteration introduces a way for diagenetic distortion of recorded external signals. It is still subject to controversy whether diagenesis simply reinforces or overprints primary variations of rock properties, or if diagenesis possibly modifies or even creates the sedimentary rhythms (e.g., Hallam 1964, 1986; Munnecke 1997; Böhm et al. 2003). Purely diagenetic rhythmites have been rejected by most researchers because of the typically observed large horizontal continuity over up to tens of kilometers of individual rhythmite layers (Böhm et al. 2003; Einsele 1982). In more recent years, studies of process-based diagenetic models have laid the foundation for more detailed investigations of diagenetic dynamics (Jenkyns 1974; Ricken 1986; Munnecke and Samtleben 1996; Westphal et al. 2000). Meanwhile computer implementations allow simulating spatial and dynamical aspects of carbonate rhythmite diagenesis (Böhm et al. 2003). Such simulations can be used to explore possible effects of diagenesis on the recording of environmental signals in calcareous rocks. Here we use this approach in order to study the recording of orbitally induced insolation changes in carbonate rhythmites (Fig. 1). As Herbert (1994) put

organized diagenetic patterns. B Cellular automata model for diagenesis simulations based on the diagenetic model of Munnecke und Samtleben (1996). With each time step, cells representing the sediment move one layer downward. Three possible states of cells are: 1 "aragonitic": consisting of aragonite, calcite, and terrigenous material; 2 "cemented": calcite cement is added; 3 "non-aragonitic": consisting of calcite and terrigenous material. Either originally aragonite-free, or diagenetically aragonite-depleted. As a layer passes through the aragonite dissolution zone, aragonite is removed from state 1 cells. For each cell where aragonite is dissolved, two cells in the cementation zone are cemented

it, any model simplifies reality, but nevertheless it can add perspective to complex subjects such as climatic frequency analysis of sediments.

Recent studies have demonstrated that differential diagenesis typical of calcareous rhythmites involves early diagenetic redistribution of sedimentary aragonite that is dissolved in marl layers and reprecipitated as calcite cement in limestone beds (Munnecke 1997; Munnecke et al. 1997; Westphal 1998; Westphal et al. 2000). The processes of early differential diagenesis of initially aragonite-bearing sediments are in contrast to diagenesis of pure calcitic sediments that are mainly altered by pressure dissolution and reprecipitation during deep burial diagenesis (Ricken 1986). The fact that aragonite-driven differential diagenesis occurs close to the sea-floor prior to the onset of mechanical compaction is manifested in the uncompacted to only slightly compacted nature of the limestone beds. During this differential diagenesis, sediment properties of limestones and marls diverge - e.g., carbonate contents of limestones increase whereas carbonate contents of marls decrease (Munnecke and Samtleben 1996). In the aragonite-based diagenesis model of Munnecke and Samtleben (1996), as implemented by Böhm et al. (2003) a three-step diagenetic process is postulated (Fig. 1A). (1) After deposition, an aragonitebearing sediment layer is slowly buried and passes through a stationary aragonite dissolution zone (presumably related to bacterial activity; see Canfield and Raiswell 1991), where aragonitic constituents are selec- 
tively dissolved. Calcite and insolubles are not affected. At least part of the dissolved calcium carbonate migrates upward by diffusion where it is reprecipitated as calcite cement, thereby drastically reducing the permeability of the overlying layer and protecting it against aragonite dissolution during its later migration through the aragonite dissolution zone. (2) When this cemented layer enters the aragonite dissolution zone, less aragonite is dissolved and consequently less dissolved calcium carbonate is available for cementing the layer above this cemented layer. (3) Upon entering the aragonite dissolution zone, this new uncemented layer again is subject to aragonite dissolution because no cementation is sealing it. This model potentially leads to a self-organized oscillation between carbonate receiver and carbonate donor beds (limestones and marls), even when starting from homogeneous sediment (Munnecke 1997). Rhythmic processes are well known to occur in geological systems at moving reaction fronts in media out of thermodynamic equilibrium (e.g., Chen et al. 1990; Hoskin 2000).

If aragonite is a limiting factor of differential diagenesis, then diagenetic redistribution of calcium carbonate can be calculated (Munnecke et al. 2001; Munnecke and Westphal 2004). It has been estimated that aragonite concentrations of 10-20\% of the original sediment are sufficient for this type of rhythmic diagenesis (Munnecke et al. 2001). This model is based on multi-proxy studies of calcareous rhythmites and explains numerous otherwise enigmatic features of calcareous rhythmites, e.g., the typically higher concentration of calcareous nannoplankton in marl layers that according to the model are passively enriched in the marls (Munnecke and Samtleben 1996; Munnecke et al. 1997; Westphal et al. 2000).

We use a cellular automata model to simulate the relevant key mechanisms of this differential diagenesis model. In this approach, macroscopic volume elements of sediment are represented as "cells", each being in one of a few simplified states, and all cells being subject to simple dynamical rules that determine how their state changes in time in dependence of the states of their neighbor cells. This coarse-grained level of abstraction allows to manage computer simulations of dynamical processes on geological scales in time and space (a strategy that proved successful, e.g., in stratigraphic simulations).

The specific model considered here consists of a twodimensional, rectangular matrix $(500 \times 800$ cells $)$ representing a vertical cut through the sediment column and with horizontal rows of cells corresponding to stratigraphic layers. Sedimentation pushes the layers downwards and a sedimentary column exits the diagenetically active region at the bottom. Each cell is in one of three states (Fig. 1B; Fig. 2): (1) aragonitic, consisting of aragonite, calcite and clay minerals; (2) cemented, where calcite cement is added to the immature sediment; and (3) non-aragonitic, either originally aragonite-free sediment consisting of calcite and clay minerals, or aragonitedepleted diagenetically mature sediment consisting of calcite and clay minerals. Aragonitic (state 1) cells can be

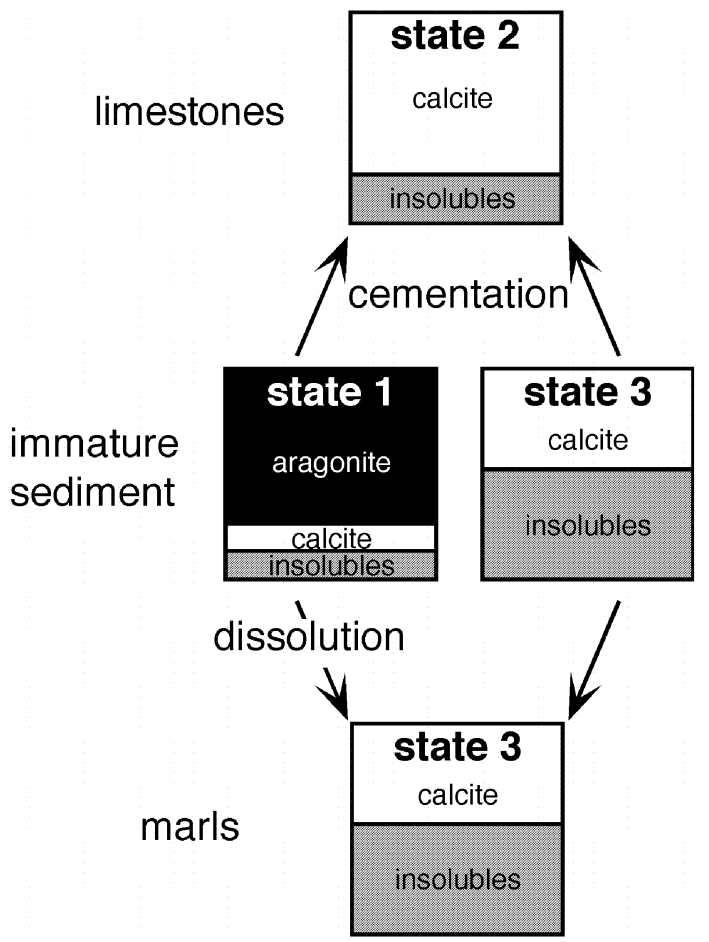

Fig. 2 States and possible transitions of the cells used in the cellular automaton. State 1 "aragonitic", consisting of aragonite, calcite and clay; state 2 "cemented", calcite cement is added to the immature sediment of state 1 or state 3 cells; state 3 "nonaragonitic", consisting of clay and calcite. State 3 cells occur as immature sediment or are generated by dissolution in state 1 cells. State 3 cells pass the dissolution zone without modification (from Böhm et al. 2003)

subject to aragonite dissolution, which transforms them into non-aragonitic (state 3) cells. Cementation, in contrast, converts aragonitic (state 1) and non-aragonitic cells (state 3 ) into cemented (state 2) cells. Layers of cemented and non-aragonitic (aragonite-depleted) cells form limestone beds and marls interbeds, respectively. With each time step, the cells of a layer are moved one layer downward. Subsequently a new, uppermost layer with new sediment is added. The sediment in the new cells is either aragonitic (state 1) or non-aragonitic (state 3). Aragonitic and non-aragonitic cells are randomly distributed in the new layer. Their relative percentage is a parameter of the model. One may vary it systematically between layers, e.g., to simulate an external trigger (see below). A dissolution zone of specified thickness of one to several layers is located in a specified depth. As a layer passes through the dissolution zone, state (1) cells are checked in random order for dissolvable aragonite. For each cell from which aragonite is dissolved, a specified number of cells in the cementation zone are instantly cemented. The cementation zone is situated at a specified distance above the aragonite dissolution zone. Both aragonitic and non-aragonitic cells can be cemented in the cementation zone. If there is no cell available for cementation, the dissolved carbonate is lost from the 
Table 1 Simulation parameters of simulation runs shown in Fig. 3. Letters refer to lettering in those figures. The following parameters were constant in all simulations: cemented cells per cells dissolved:

\begin{tabular}{|c|c|c|c|c|c|c|}
\hline & A & B & $\mathrm{C}$ & $\mathrm{D}$ & $\mathrm{E}$ & $\mathrm{F}$ \\
\hline Cementation layer thickness & 5 & 3 & 5 & 5 & 5 & 5 \\
\hline Depth of dissolution layer top & 55 & 50 & 490 & 45 & 35 & 25 \\
\hline Time step & $1 \mathrm{ka}$ & $1 \mathrm{ka}$ & $0.1 \mathrm{ka}$ & $1 \mathrm{ka}$ & $1 \mathrm{ka}$ & $1 \mathrm{ka}$ \\
\hline Simulated time steps & 3003 & 3003 & 30030 & 3003 & 3003 & 3003 \\
\hline
\end{tabular}

2; seeding probability: 0.5. A detailed description of the models run is available as supplementary material; a discussion of the model system. For a detailed description of the cellular automata model setup, the reader is referred to Böhm et al. (2003).

In this rhythmic diagenesis model, diagenesis may produce self-organized layers in carbonate sediments by a process of aragonite dissolution and calcite reprecipitation. During early sediment burial, early-cemented limestone beds may interact with the dissolution zone inducing a feedback mechanism that may result in oscillatory modulation of bed formation ("diagenetic oscillator"; Böhm et al. 2003). Combining this diagenetic oscillator with a weak external signal results in lateral correlation of the oscillations manifested as layers (i.e., external signals correlate layers, however, they are not needed for initiation of layer- or nodule-formation itself). Whereas input mineralogy is directly controlled by orbital cycles, the diagenetic oscillator is depth-related and not timerelated and is controlled by internal feedback. The feedback mechanism between the aragonite contents and the diagenetic oscillator is realized by the variation in cementation depending on primary aragonite in the pristine sediment.

Let us here translate temporally varying insolation into a sediment property by modulating the aragonite contents of a newly deposited layer as a linear function of summer insolation at $65^{\circ} \mathrm{N}$ (Berger and Loutre 1991). In nature, such variations in aragonite can result, e.g., from sea-level fluctuations (Droxler et al. 1983). We then investigate the possible modification of the sedimentary manifestation of orbital signals in carbonate successions by diagenetic processes. Several simulation runs were carried out with different depths of the diagenetic zones (aragonite dissolution and cement precipitation), resulting in diagenetic cycles of variable frequencies (Table 1).

During continuing diagenesis, uncemented marl beds will undergo strong compaction, whereas the cemented layers will not be subject to considerable mechanical compaction (e.g., Munnecke et al. 1997; Westphal and Munnecke 1997; Westphal et al. 2000). This compaction results in additional distortions and in uncertainties of depth-to-time transformation (cf. Hinnov 2000). For the simulations presented here, the further distortion of the primary signal by differential compaction is not considered. The frequency analyses shown here deal with the uncompacted sediment column that represents the time domain and corresponds to the decompacted succession.

\section{Results}

In the model simulation, the (external) cyclicity imposed on the sedimentary succession by the varying aragonite input interacts with the (internal) diagenetic dynamics and leads to interesting and unexpected dynamical effects. Our main observation is that this interaction leads to complicated modifications in the recording of the external signal in the sediment.

Firstly, varying the diagenetic frequency by employing different depths of the diagenetic zones, while using an identical insolation signal in every simulation run, results in distinctly different diagenetically mature limestonemarl rhythmites (Fig. 3-I). The resulting rhythmites vary with respect to lateral continuity of the individual layers (continuous in Fig. 3-I C; discontinuous in Fig. 3-I A), layer thickness (thicker in Fig. 3-I F than in Fig. 3-I E), and bundling of the layers (i.e. larger scale-variations of thickness of limestone layers and/or marl interbeds; e.g. Fig. 3-I B and 3-I C).

Furthermore, spectral analyses (maximum entropy method) demonstrate the type of distortions of the insolation signals in more detail (Fig. 3-II). Four different types of distortions are observed: (1) Diagenesis can modify the amplitudes of the cycles of sediment composition generated by varying insolation. It can amplify originally weak signals (e.g. the $11 \mathrm{ka}$ peak in Fig. 3-IIC). (2) New frequencies not represented in the insolation curve can emerge (e.g., $12 \mathrm{ka}$ and $114 \mathrm{ka}$ peaks in Fig. 3IIA. (2) Spectral peaks present in the frequency spectrum of the insolation curve can be suppressed (e.g. the $21 \mathrm{ka}$ peak in Fig. 3-IIF). (3) Spectral peaks of the insolation spectrum can be displaced towards higher or lower frequencies (e.g. the 41-ka peak in Fig. 3-IIB). Thus, the simulations demonstrate that the inherent dynamics of differential diagenesis, typical for many calcareous rhythmites, has the potential to severely modify the record of primary (orbital) signals.

\section{Discussion}

The modifications of the diagenetic frequencies and amplitudes can lead to seriously misleading results and therefore have strong implications for the interpretation of the signal recorded in the rock record. In calcareous rhythmites that have undergone differential diagenesis, peaks in spectral analyses do not necessarily reflect 
Fig. 3 Examples of simulated calcareous rhythmites. I Simulated lithologic columns based on identical insolation-determined sediment composition (insolation [Berger and Loutre 1991]: blue curve at left), but on different diagenetic cycle wavelength ( column top). $A$ Diffuse beds and bundles. $B$ Clear bundles, more distinct beds. $C$ 100-ka bundles of beds, first in phase with diagenetic cycle, shift to phase-lock with the insolation cycle. Green curve diagenetic frequency; red curve percentage of cement. $D$ Diffuse bedding. Diagenetic cyclicity lacks resonance with any insolation period. $E$ Distinct beds, weak bundling. Strong resonance between diagenetic cycle and precession, no resonance with obliquity. $F$ Precessional beds are suppressed, strong obliquity periods. II Power spectra of the simulated rhythmic sequences (cement content, red curve) compared to insolation spectra (initial aragonite content, blue curve). Letters indicate matching successions in Fig. 3-I. Amplification: Minor peak in the insolation spectrum $(11 \mathrm{ka})$ is amplified by resonance with the diagenetic cyclicity. (Note: diagenetic cement spectrum in a succession without orbital signals [dashed curve] shows harmonics due to the rectangular shape of the diagenetic cycles.) Emergence: spectral peaks (114 ka and $12 \mathrm{ka}$ ) not present in the input signal emerge. Suppression: precession frequencies are suppressed. Displacement: obliquity cycle period (41 ka) displaced towards shorter wavelength. $M E M=$ maximum entropy method
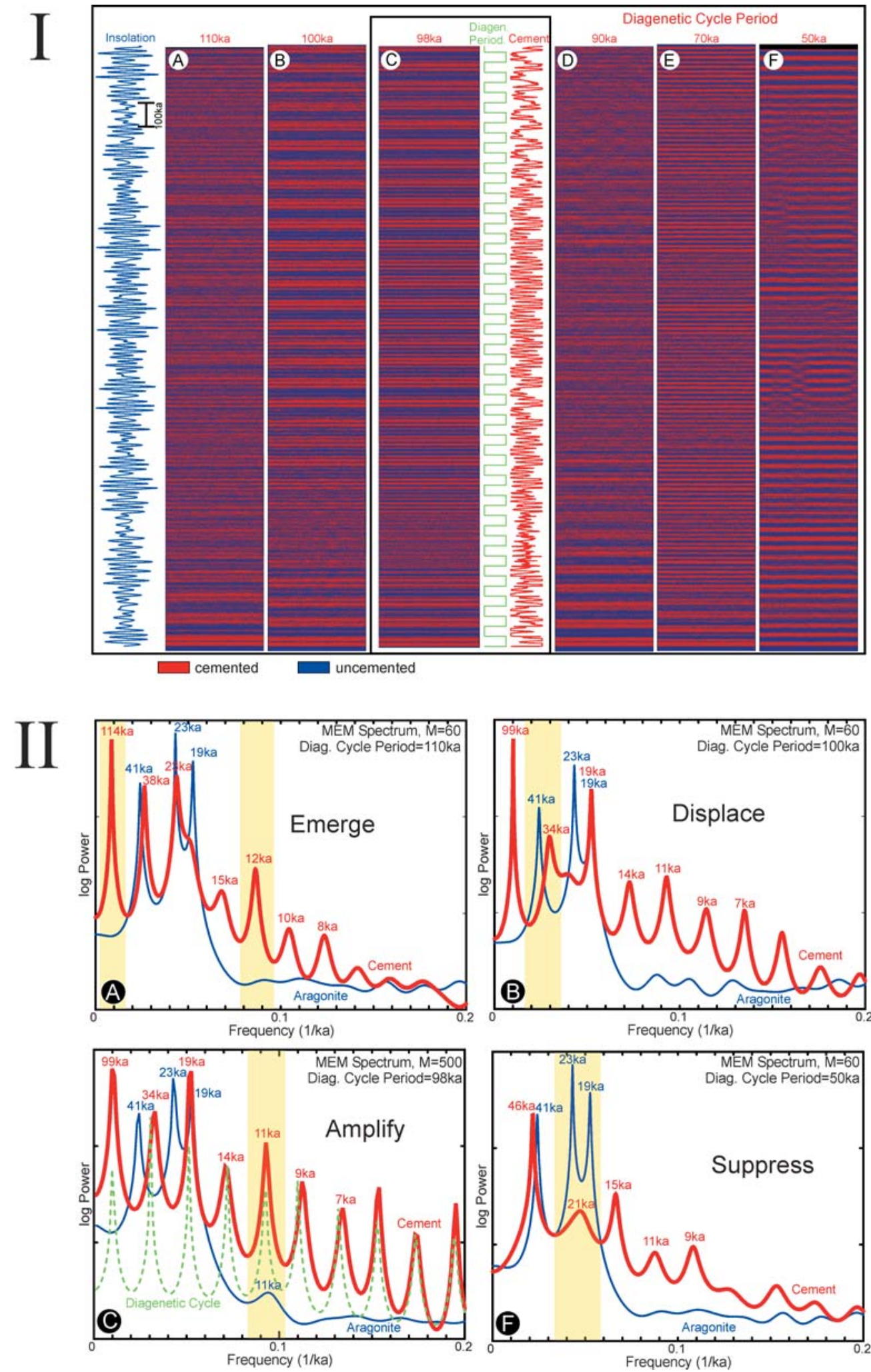

primary signals. Especially when undertaking orbital tuning, power can be shifted from diagenetically caused frequencies to orbital frequencies (cf. Shackleton et al. 1995). On the other hand, a lack of clear orbital cycles in a carbonate sequence does not necessarily imply that it was not forced by orbital cycles - they could be disguised by diagenesis. For assessing the presence and nature of pre-diagenetic differences in calcareous sediments, diagenetically inert parameters need to be carefully examined. Rock properties commonly used for frequency 
analyses such as sonic velocity, natural gamma ray, and carbonate contents are influenced by diagenesis. In contrast, diagenetically inert parameters that are not influenced by redistribution of calcium carbonate during diagenesis include for example palynomorph assemblages (not the absolute quantities per gram sediment!) and the ratio of immobile chemical elements (again: not the quantities!) (e.g., Munnecke et al. 2001; Westphal et al. 2004). Several studies have shown that in the calcareous rhythmites examined, no unequivocal and diagenetically robust manifestation of rhythmic climate change was detected, implying that interpretation has to be undertaken with caution (e.g., Hallam 1964, 1986; Jenkyns 1974; Eder 1982; Munnecke and Samtleben 1996; Westphal et al. 2000, 2004). Clearly there is nothing like homogeneous sediment, however the absence of unequivocal primary differences suggests that there were no pronounced systematic variations as cause for the rhythmic calcareous alternations. Diagenetically inert parameters that fluctuate on a larger scale than the rhythmic alternations (e.g., Westphal et al. 2004) could reflect the larger scale climate signal that acted as external synchronization mechanism of diagenesis.

Beyond simply questioning straightforward interpretation of calcareous rhythmites, our model results offer a solution to several problems of the astronomical theory. The diagenetic phenomena observed in the simulations (amplitude modification, suppression, displacement, emergence) provide a possible explanation for several of the controversial phenomena observed in real-world calcareous rhythmites:

The lack of systematic differences in palynomorph assemblages between limestones and marls as observed e.g. by Courtinat (1993) and Westphal et al. (2004) is in accord with the hypothesis that in a system severely influenced by differential diagenesis, the position of limestone and marl layers in the sedimentary column is not necessarily consistent with initial orbitally forced variations. It demonstrates how "non-orbital" frequencies can arise naturally through diagenetic post-depositional processing of the sedimentary record, and provides a mechanism for the occurrence of amplitude shifts. Such an oscillatory feedback could potentially mimic orbital forcing.

The observed discrepancy between power spectra of different measured parameters (e.g., Eberli 2000) could reflect the different sensitivity of those parameters to diagenetic overprint. The diagenetic oscillator implemented in our model depends on an external trigger as synchronization mechanism. A strong sudden event could act as such a trigger, causing the diagenetic system to reverberate strongly and produce pronounced limestonemarl rhythms. Calcareous sediments deposited prior to the trigger event might show slight variations in numerous parameters that suddenly increase in their amplitudes after an external event synchronized and excited diagenetic oscillations. With the lack of a further synchronization mechanism, this cyclicity slowly decays and gives way to a rather chaotic succession of limestone and marl layers (Böhm et al. 2003). This could possibly explain a behavior as that observed for the aftermath of the $\mathrm{K} / \mathrm{T}$ boundary event described before (D'Hondt et al. 1996).

Thus, carbonate redistribution during differential diagenesis does not only result in a modification of the amplitude of the primary signal (Ricken 1986, 1987), but also in a forgery of the record of primary cyclicity that might not be easily detected. Missing out such a distortion could lead to incorrect results of cyclostratigraphic and chronostratigraphic interpretations.

\section{Conclusions}

We conclude that straightforward use of calcareous rhythmites as chronostratigraphic tool is problematic. There may have been over-ambitious interpretations in the past that have not considered possible diagenetic distortions as the ones discussed here. Orbital tuning appears particularly questionable in calcareous rhythmites, where only diagenetically instable parameters (such as carbonate content) are considered. Similarly, the interpretation of peak heights to estimate the amplitude of environmental change (such as sea-level fluctuations) on the basis of limited parameters is prone to misinterpretations. A renewed view of the diagenesis problem of calcareous rhythmites demonstrates that paleoclimatic interpretations based on relative peak heights, cyclostratigraphic correlation, and chronostratigraphic orbital calibration may produce misleading results and need to be undertaken with extreme caution.

Acknowledgements The authors are indebted to Axel Munnecke for inspiring discussions and revision of a previous version of the manuscript. Reviews by Roy Plotnick and Graham Weedon considerably improved this paper. This project was supported by the German Science Foundation DFG (We-2492/1).

\section{References}

Arthur MA, Bottjer DJ, Dean WE, Fischer AG, Hattin DE, Kaufmann EG, Pratt LM (1986) Rhythmic bedding in Upper Cretaceous pelagic carbonate sequences: varying sedimentary response to climatic forcing. Geology 14:153-156

Barron EJ, Arthur MA, Kauffman EG (1985) Cretaceous rhythmic bedding sequences; a plausible link between orbital variations and climate. Earth Planet Sci Lett 72:327-340

Bathurst RGC (1971) Carbonate sediments and their diagenesis. Developments in sedimentology: 12, Elsevier, Amsterdam, 620 pp

Bathurst RGC (1987) Diagenetically enhanced bedding in argillaceous platform limestones: stratified cementation and selective compaction. Sedimentology 34:749-778

Bathurst RGC (1991) Pressure-dissolution and limestone bedding: the influence of stratified cementation. In: Einsele G, Ricken W, Seilacher A (eds) Cycles and events in stratigraphy. Springer, Berlin Heidelberg New York, pp 450-463

Bellanca A, Claps M, Erba E, Masetti D, Neri R, Premoli Silva I, Venezia F (1996) Orbitally induced limestone/marlstone rhythms in the Albian-Cenomanian Cismon section (Venetian region, northern Italy); sedimentology, calcareous and siliceous plankton distribution, elemental and isotope geochemistry. Palaeogeogr Palaeoclimatol Palaeoecol 126:227-260 
Berger A, Loutre MF (1991) Insolation values for the climate of the last 10 million of years. Quat Sci Rev 10:297-317

Böhm F, Westphal H, Bornholdt S (2003) Required but disguised: environmental signals in limestone-marl alternations. Palaeogeogr Palaeoclimatol Palaeoecol 189:161-178

Canfield DE, Raiswell R (1991) Carbonate precipitation and dissolution. In: Allison PA, Briggs DEG (eds) Taphonomy: releasing the data locked in the fossil record. Plenum Press, New York, pp 412-453

Chen W, Ghaith A, Park A, Ortoleva PJ (1990) Diagenesis through coupled processes; modeling approach, self-organization, and implications for exploration. In: Meshri ID, Ortoleva PJ (eds): Prediction of reservoir quality through chemical modeling. AAPG Mem 49:103-130

Cleaveland LC, Jensen J, Goese S, Bice DM, Montanari A (2002) Cyclostratigraphic analysis of pelagic carbonates at Monte dei Corvi (Ancona, Italy) and astronomical correlation of the Serravallian-Tortonian boundary. Geology 30:931-934

Courtinat B (1993) The significance of palynofacies fluctuations in the Greenhorn Formation (Cenomanian-Turonian) of the Western Interior Basin, USA. Mar Micropaleontol 21:249-257

de Boer PL, Smith DG (1994) Orbital forcing and cyclic sequences. IAS Spec Publ 19:559

de Boer PL, Wonders AAH (1984) Astronomically induced rhythmic bedding in Cretaceous pelagic sediments near Moria (Italy). In: Berger A, Imbrie J, Hays J, Kukla G, Saltzman B (eds) Milankovitch and climate. Hingham, Massachusetts, pp 177-190

D'Hondt S, King J, Gibson C (1996) Oscillatory response to the Cretaceous-Tertiary impact. Geology 24:611-614

Droxler AW, Schlager W, Whallon CC (1983) Quaternary aragonite cycles and oxygen-isotope record in Bahamian Carbonate ooze. Geology 11:235-239

Dullo W-C (1984) Progressive diagenetic sequence of aragonite structures: Pleistocene coral reefs and their modern counterparts on the eastern Red Sea coast, Saudi Arabia. Palaeontograph Americana: 54:254-260

Eberli GP (2000) The record of Neogene sea-level changes in the prograding carbonates along the Bahamas Transect-Leg 166 synthesis. Proceedings of the Ocean Drilling Program, Scientific Results, 166:167-177

Eder W (1982) Diagenetic redistribution of carbonate, a process in forming limestone-marl alternations (Devonian and Carboniferous, Rheinisches Schiefergebirge, W. Germany). In: Einsele G, Seilacher A (eds) Cyclic and event stratification. Springer, Berlin Heidelberg New York, pp 98-112

Einsele G (1982) Limestone-marl cycles (periodites): diagnosis, significance, causes - a review. In: Einsele G, Seilacher A (eds) Cyclic and event stratification. Springer, Berlin Heidelberg New York, pp 8-53

Einsele G, Ricken W, Seilacher A (1991) Cycles and events in stratigraphy. Springer, Berlin Heidelberg New York, 955 pp

Elkibbi M, Rial JA (2001) An outsider's review of the astronomical theory of the climate: is the eccentricity-driven insolation the main driver of the ice ages? Earth-Sci Rev 56:161-177

Fischer AG, Bottjer DJ (1990) Orbital forcing and sedimentary sequences. J Sediment Petrol 61:1063-1252

Frank TD, Arthur MA, Dean WE (1999) Diagenesis of Lower Cretaceous pelagic carbonates, North Atlantic: Paleoceanographic signals obscured. J Foramin Res 29:340-351

Hallam A (1964) Origin of limestone-shale rhythm in the Blue Lias of England: a composite theory. J Geol 72:157-169

Hallam A (1986) Origin of minor limestone-shale cycles: climatically induced or diagenetic? Geology 14:609-612

Hays JD, Imbrie J, Shackleton NJ (1976) Variations in the Earth's orbit: pacemaker of the ice ages. Science 194:1121-1132

Herbert TD (1994) Reading orbital signals distorted by sedimentation: models and examples. In: de Boer PL, Smith DG (eds) Orbital forcing and cyclic sequences. IAS Spec Publ 19:438507
Herbert TD, Fischer AG (1986) Milankovitch climatic origin of mid-Cretaceous black shale rhythms in central Italy. Nature 321:739-743

Hilgen FJ, Abdul Aziz H, Krijgsman W, Raffi I, Turco E (2003) Integrated stratigraphy and astronomical tuning of the Serravallian and lower Tortonian at Monte dei Corvi (MiddleUpper Miocene, Northern Italy). Palaeogeogr Palaeoclimatol Palaeoecol 199:229-264

Hilgen FJ, Lourens LJ, Berger A, Loutre MF (1993) Evaluation of the astronomically calibrated time scale for the late Pliocene and earliest Pleistocene. Paleoceanography 8:549-565

Hinnov L, Park J, Erba E, Smith PL (2000) Lower-Middle Jurassic rhythmites from the Lombard Basin, Italy; a record of orbitally forced carbonate cycles modulated by secular environmental changes in West Tethys. Advances in Jurassic research 2000; Fifth international symposium on the Jurassic system, 6:437453

Hinnov LA (2000) New perspectives on orbitally forced stratigraphy. Ann Rev Earth Planet Sci 28:419-475

Hoskin PWO (2000) Patterns of chaos: fractal statistics and the oscillatory chemistry of zircon. Geochim Cosmochim Acta 64:1905-1923

Jenkyns HC (1974) Origin of red nodular limestones (Ammonitico Rosso, Knollenkalke) in the Mediterranean Jurassic: a diagenetic model. In: Hsü KJ, Jenkyns HC (eds) Pelagic sediments: on land and under the sea. Int Assoc Sedimentol Spec Publ $1: 249-271$

Kominz MA (1996) Whither cyclostratigraphy? Testing the gamma method on upper Pleistocene deep-sea sediments, North Atlantic Deep Sea Drilling Project Site 609. Paleoceanography $11: 481-504$

Munnecke A (1997) Bildung mikritischer Kalke im Silur auf Gotland. Courier Forschungsinstitut Senckenberg 198:1-71

Munnecke A, Samtleben C (1996) The formation of micritic limestones and the development of limestone-marl alternations in the Silurian of Gotland, Sweden. Facies 34:159-176

Munnecke A, Westphal H (2004) Shallow-water aragonite recorded in bundles of limestone-marl alternations - the Upper Jurassic of SW Germany. Sediment Geol (in press)

Munnecke A, Westphal H, Elrick M, Reijmer JJG (2001) The mineralogical composition of precursor sediments of calcareous rhythmites: a new approach. Int J Earth Sci 90:795-812

Munnecke A, Westphal H, Reijmer JJG, Samtleben C (1997) Microspar development during early marine burial diagenesis: a comparison of Pliocene carbonates from the Bahamas with Silurian limestones from Gotland (Sweden). Sedimentology 44:977-990

Reinhardt EG, Cavazza W, Patterson RT, Blenkinsop J (2000) Differential diagenesis of sedimentary components and the implication for strontium isotope analysis of carbonate rocks. Chem Geol 164:331-343

Ricken W (1986) Diagenetic bedding: a model for limestone-marl alternations. Lecture notes in Earth Sci 6. Springer, Berlin Heidelberg New York, $210 \mathrm{pp}$

Ricken W (1987) The carbonate compaction law: a new tool Sedimentology 34:1-14

Ricken W (1992) A volume and mass approach to carbonate diagenesis: the role of compaction and cementation. In: Wolf $\mathrm{KH}$, Chilingarian GV (eds) Diagenesis III. Dev Sedimentol 47:291-315

Schiffelbein P, Dorman L (1986) Spectral effects of time-depth non-linearities in deep sea sediment records: a demodulation technique for realigning time and depth scales. J Geophys Res 91:3821-3835

Schwarzacher W (1987a) Astronomical cycles for measuring geological time? Mod Geol 11:375-381

Schwarzacher W (1987b) Astronomically controlled cycles in the Lower Tertiary of Gubbio (Italy). Earth Planet Sci Lett 84:2226

Shackleton NJ, Hall MA, Pate D (1995) Pliocene stable isotope stratigraphy of Site 846. In: Pisias NG, Mayer LA, Janecek TR, 
et al. (eds) Proceedings of the Ocean Drilling Program 138:337-357

Shackleton NJ, Hall MA, Raffi I, Tauxe L, Zachos J (2000) Astronomical calibration age for the Oligocene-Miocene boundary. Geology 28:447-450

Weedon GP (1989) The detection and illustration of regular sedimentary cycles using Walsh power spectra and filtering, with examples from the Lias of Switzerland. J Geol Soc Lond 146:133-144

Weedon GP (2003) Time-series analysis and cyclostratigraphy. Examining stratigraphic records of environmental signals. Cambridge University Press, Cambridge, 274 pp

Westphal H (1998) Carbonate platform slopes-a record of changing conditions; Lecture Notes in Earth Sci 75. Springer, Berlin Heidelberg New York, 179 pp
Westphal H, Head MJ, Munnecke A (2000) Differential diagenesis of rhythmic limestone alternations supported by palynological evidence. J Sediment Res 70:715-725

Westphal H, Munnecke A (1997) Mechanical compaction versus early cementation in fine-grained limestones: differentiation by the preservation of organic microfossils. Sediment Geol 112:33-42

Westphal H, Munnecke A, Pross J, Herrle JO (2004) The origin of Cretaceous pelagic limestone-marl alternations (DSDP Site 391, Blake-Bahama Basin): a multi-proxy approach poses new questions. Sedimentology 51:109-126 